Legal Update

\title{
Poetic justice for owners of database right
}

\section{Ewan Nettleton}

is a Senior Associate Solicitor in the Intellectual Property Department at Bristows. He specialises in Intellectual Property Law with an emphasis on litigation. He has an MA in Chemistry and a D.Phil. in Protein Chemistry and is particularly interested in matters relating to the IT and pharmaceutical industries.

ABSTRACT How times have changed since the European Court of Justice's (ECJ) ruling in the British Horseracing Board and Fixtures Marketing cases 4 years ago. Those decisions had led many commentators to think that database right was dead and buried, with few databases able to benefit from protection. However, the ECJ's ruling in the Directmedia case (C-304/07) handed down in October 2008 has reinvigorated the right. The ECJ has spoken, and database owners such as database marketers will be gratified to hear that the Advocate General's opinion reported in the last issue was largely followed. The outcome and implications of the ruling are summarised below.

Journal of Database Marketing \& Customer Strategy Management (2009) 16, 57-60.

doi:10.1057/dbm.2009.2

Keywords: database right; poems; extraction; Directmedia Publishing;

European Court of Justice

\section{DATABASE RIGHT AND THE PREVIOUS CASES}

As regular readers of the Journal will know, database right is one of the 'newer' intellectual property rights, which, just over a decade since its creation, is still finding its feet in terms of what it covers and the protection it affords. Importantly, in contrast to copyright, which can also protect databases but requires a degree of creativity, database right protects the investment that is made in the creation and upkeep of a database where that investment is sufficiently substantial.

Of the previous decisions that have considered the right, by far the most significant were those handed down in the British Horseracing Board (BHB) and
Fixtures Marketing cases ${ }^{1}$ summarised in earlier articles. ${ }^{2}$ The database owners in those cases were in the business of creating data - lists of runners and riders for horse races and lists of football fixtures, respectively - and one of the key issues they came up against was whether their investment in 'obtaining' the data counted towards the 'substantial' investment needed for their databases to be protected by database right. In what many commentators saw as a fairly harsh decision, this investment was held not to count, and, to compound the database owners' troubles, the European Court of Justice (ECJ) also held that the intrinsic value of the data taken by an alleged infringer could not be taken into account when assessing 
whether the data taken amounted to the substantial part required for infringement.

The database owners in BHB and Fixtures Marketing therefore suffered on two counts their investment in the creation and upkeep of the databases (as compared with the investment in generating the data) was not substantial enough for database right protection in their databases to subsist, and, even if it had been so, the alleged infringing activities, which could be seen as 'cherry picking' the most interesting data, would probably not have amounted to infringement. The bigger picture for database owners was that these decisions greatly weakened what many commentators had initially thought to be a potentially strong intellectual property right.

The one chink of light for database owners in BHB and Fixtures Marketing was the fact that the ECJ's consideration of the infringing acts of 'extraction' and 'reutilisation', although of little help to the BHB and Fixtures Marketing, suggested that infringement would occur irrespective of whether access to the database was made directly or indirectly via some intermediary medium. This was perhaps an indication of the activities that infringed the right being quite broad at least in this respect.

\section{THE FACTS AND ISSUES IN DIRECTMEDIA}

The ECJ has now handed down its decision in Directmedia, a case concerning databases containing poems, which is the first really significant case on fundamental principles that apply to database right since $B H B$ and Fixtures Marketing. The database in question can perhaps be thought of as a more 'traditional' type of database than those at issue in the BHB and Fixtures Marketing cases. It is not so much that the database's contents - historic German poetry - were a good deal older than the data considered in the BHB and Fixtures Marketing cases. Rather, the database was more 'traditional' in the sense that it was a collection of preexisting information that had been brought together to create a database. The database consisted of a collection of details of preexisting works rather than being a repository for data generated as part of a company's day-to-day business. Also, all of the data were of potential interest to those wanting to study the relevant subject matter, as opposed to only the most interesting or up-to-date information.

These circumstances meant that the position of the owner of the original database in the Directmedia case, a German university, was quite different and a lot stronger than that of the database owners in the BHB and Fixtures Marketing cases. It was clear that a lot of work had gone into the creation of the university's database. When selecting the poems to include in the 1100 most important poems in German literature between 1730 and 1900, the university professor had made his selection from works comprising some 20000 poems. The database listed the titles, arranged according to the frequency with which they were cited, and included information on the author, title, opening line and year of publication for each poem. As part of the statistical analysis that was involved in the database's creation, the titles and opening lines of the poems were standardised, and both the works in which the poems were published and their date of composition were identified. The entire project took approximately 2.5 years, and the costs amounted to just shy of 35000 euros. The question of whether there had been substantial investment in the database was not therefore something the ECJ had to decide.

Additionally, this was not a case of 'cherry picking', just the most interesting or up-to-date data. Directmedia's CD-ROM containing '1000 poems everyone should have' comprised 876 poems dating from the relevant time period, 856 (almost 98 per cent) of which were also mentioned in the 
list of poems drawn up by the university professor. The question as to whether a substantial part of the database had been taken was not therefore something the ECJ had to grapple with.

Instead, the question referred to the ECJ arose from the fact that, rather than mechanically copying the contents of the university's database and incorporating them into its CD-ROM, Directmedia had examined each of the poems the university professor had selected critically. Having done so, it had decided against adding some and chosen to add in others, and had also included additional data of its own for each of the poems it selected. The question put to the ECJ was whether this sort of 'adaptation' copying fell within the meaning of the act of 'extraction', which would infringe the university's database right.

\section{THE ECJ'S RULING}

Adopting much of the reasoning of Advocate General Sharpston who delivered an opinion ${ }^{3}$ on the case a few months before as discussed in the last issue, the ECJ held that the infringing act of 'extraction' should be interpreted broadly with the sort of copying carried out by Directmedia being covered. It rejected Directmedia's contention that only acts consisting of mechanical reproduction, without adaptation, by a standard 'copy/paste' process could fall within the definition. It was held to be immaterial for the purposes of interpreting the concept of extraction that the transfer of the protected database's contents led to an arrangement of the data that was different to the original database. Furthermore, the fact (on which Directmedia placed considerable reliance) that the alleged infringing act involved the transfer of only part of the material contained in the protected database and that the material transferred was complemented by additional material from elsewhere was held to show, at the very most, only that the transfer did not relate to the whole of the database contents. It did not detract from the transfer being an extraction.

Additionally, the ECJ considered that although the carrying out of a critical assessment of the original database's contents before making the selection and transfer could be relevant to determining whether the new database created was eligible for protection from database right of its own, this did not preclude a finding that the act of transfer infringed the database right in the original database. Indeed, referring to the BHB and Fixtures Marketing cases, the ECJ confirmed that it is of little importance that the act of transfer in question is for the purpose of creating another database (as opposed to being for some other purpose). Likewise, whether the new database created is in competition with the original database and whether it is the same or different in size from the original have no bearing.

The ECJ also made a further more general finding that would have come as no surprise to commentators familiar with the interpretation of European legislation. As they would expect, the ECJ held that the references to specific types of infringement in the preamble to the Database Directive, which the German Court that referred the question to the $\mathrm{ECJ}^{4}$ suggested might militate in favour of a restrictive interpretation of 'extraction', were merely illustrative and did not confine its definition.

\section{CONCLUSIONS}

The take-home point from this decision for database owners such as database marketers is that the ECJ has confirmed that 'extraction' is defined broadly, and transfer following an on-screen consultation and an individual assessment of a database's content can fall within it. In this respect, which was the only material issue before the European Court, database right has certainly been strengthened, and owners of what one might term more 'traditional' databases that comprise collections of pre-existing data, all of which are potentially useful to would-be 
infringers, are in a stronger position than they were before the Directmedia decision. Although owners of databases created as part and parcel of a company's business activities are still left wondering whether their databases are protected, even they can feel assured that, if database right does subsist, it should give a strong level of protection.

\section{REFERENCES AND NOTES}

1 The British Horseracing Board and Others $v$ William Hill Organisation Ltd, Judgment of the Court (Grand Chamber), 9 November 2004, Case C-203/02, and the associated cases involving Fixtures Marketing, C-46/02, C-444/02 and C-338/02 in which judgments were handed down on the same day.

2 Nettleton, E. and Obhi, H. (2004) Database right Place your bets. Journal of Database Marketing and Customer Strategy Management 11(4): 373-378;

Nettleton, E. and Obhi, H. (2004) Legal protection of databases: A wider transatlantic divide? Journal of Database Marketing and Customer Strategy Management 12(1): 80-86; Nettleton, E. and Obhi, H. (2004) ECJ rules on protection afforded by database right. Journal of Database Marketing and Customer Strategy Management 12(3): 266-271.

3 Opinion of Advocate General Sharpston in Case C-304/07 delivered on 10 July 2008.

4 The Bundesgerichtshof (Federal Court of Justice). 